\title{
Gambaran karakteristik gagal jantung pada bayi baru lahir di RSUP Prof. Dr. R. D. Kandou Manado periode tahun 2013-2015
}

\author{
${ }^{1}$ Reggie C. Gautama \\ ${ }^{2}$ Erling D. Kaunang \\ ${ }^{2}$ Suryadi N. N. Tatura \\ ${ }^{1}$ Kandidat Skripsi Fakultas Kedokteran Universitas Sam Ratulangi Manado \\ ${ }^{2}$ Bagian/SMF Ilmu Kesehatan Anak Fakultas Kedokteran \\ Universitas Sam Ratulangi Manado \\ Email: reggie.rcg12@gmail.com
}

\begin{abstract}
Heart failure is one of the cardiovascular diseases to be the focus of attention. This study was aimed to obtain the characteristics of heart failure in newbornsat Prof. Dr. R. D. Kandou Hospital Manado in 2013-2015. This was a retrospective descriptive study with a cross-sectional design using data of medical records in Department of Pediatrics and Medical Records Center of Prof. Dr. R. D. Kandou Hospital Manado. The results showed that there were 22 samples consisted of males 55\% and females $45 \%$.Clinical manifestations were as follows: fever $(68 \%)$, cyanosis $(64 \%)$, and breathing difficulty $(45 \%)$. The physical examinations that were taken into account were vital signs (pulse: $152.86 \mathrm{x} /$ minute; respiration rate: $70.59 \mathrm{x} /$ minute; body temperature: $36.86^{\circ} \mathrm{C}$ ), anthropometry (body weight: 3495.45 grams), head examination (anemic conjunctiva: 9\%; icteric sclera: 42\%), lung examination (retraction: 95\%, ronchi: 14\%), and heart examination (pansystolic murmur: $82 \%$; systolic ejection murmur: $14 \%$ ). The supportive workups that were taken into account included echocardiography (VSD: 68\%; ASD: 9\%; ASD and VSD: 9\%; other congenital heart diseases: 14\%), chest X-ray (normal: 91\%; infiltrate spots in both lungs: 9\%), and laboratory tests (low $\mathrm{Ht}$ count $45 \%$; low $\mathrm{Hb}$ count 55\%; low platelet count 68\%; high leukocyte count $73 \%$; high level of total bilirubin $77 \%$; high level of direct bilirubin $73 \%$; electrolytes (within normal limit: calcium 50\%; sodium $46 \%$, potassium $68 \%$; and chloride 54\%). Conclusion: In this study, the most dominant gender was male, and the clinical manifestations as follows: fever, cyanosis, and breathing difficulty; physical examination as follows: tachycardia, tachypnea, hypothermia, hyperthermia, icteric sclera, prominent retraction, and pansystolic murmur. Meanwhile, in the supportive workups the most common manifestations were VSD in echocardiography, and the laboratory tests as follows: decreased hematocrit count, hemoglobin, and platelets, and increased leukocyte count, and total and direct bilirubin levels.
\end{abstract}

Keywords: characteristics, heart failure, newborn infant

\begin{abstract}
Abstrak: Gagal jantung merupakan salah satu penyakit kardiovaskular yang menjadi fokus perhatian. Penelitian ini bertujuan untuk mengetahui gambaran karakteristik penderita gagal jantung pada bayi baru lahir di RSUP Dr. R. D. Kandou Manado tahun 2013-2015.Jenis penelitian ialah deskriptif retrospektif dengan desain potong lintang menggunakan data rekam medik di Bagian Ilmu Kesehatan Anak dan Pusat Rekam Medik RSUP Dr. R. D. Kandou Manado. Hasil penelitian mendapatkan sebanyak 22 sampel, terdiri dari sampel lakilaki sebanyak 55\% dan perempuan 45\%. Gambaran klinis berupa demam (68\%), sianosis (64\%) dan sesak napas (45\%). Pemeriksaan fisik yang dinilai berupa tanda vital (nadi: 152,86x/menit; respirasi: $70,59 \mathrm{x} /$ menit; suhu: $36,86^{\circ} \mathrm{C}$ ), antropometri (berat badan: 3495,45 gram), pemeriksaan kepala (konjungtiva anemis: 9\%; sklera ikterik: 42\%), pemeriksaan paru-paru (retraksi: 95\%; rhonki: 14\%) dan pemeriksaan jantung (bising pansistolik: 82\%;
\end{abstract}


bising;ejeksi sistolik: 14\%). Pemeriksaan penunjang ialah ekokardiografi (VSD: 68\%; ASD: 9\%; ASD dan VSD: 9\%; PJB lainnya: 14\%), foto toraks (normal: 91\%; bercak infiltrat pada kedua lapang paru: 9\%) dan pemeriksaan laboratorium ( $\mathrm{Ht}$ rendah $45 \%$; $\mathrm{Hb}$ rendah $55 \%$; trombosit rendah 68\%)leukosit tinggi 73\%; kadar bilirubin total tinggi (77\%); kadar bilirubin direk tinggi (73\%); elektrolit (dalam batas normal: kalsium (50\%), natrium (46\%), kalium (68\%), dan klorida (54\%)) normal). Simpulan: Dalam studi ini yang terbanyak ditemukan ialah jenis kelamin laki-laki, temuan klinis demam, sianosis dan sesak napas, pemeriksaan fisik takikadia, takipneu, hipotermi dan hipertermi, sklera ikterik, retraksi, dan bising pansistolik.Pada pemeriksaan penunjang terbanyak ditemukan ialah VSD pada ekokardiografi dengan hasil laboratorium penurunan hematokrit, hemoglobin, dan trombosit serta peningkatan leukosit, bilirubin total, dan direk.

Kata kunci: karakteristik, gagal jantung, bayi baru lahir

Jantung berfungsi sebagai pompa yang dibagi menjadi sisi kanan dan kiri, masingmasing dibagi menjadi bagian atas dan bawah. Bagian atas disebut atrium, yang akan menerima darah dari seluruh tubuh dan memompanya melalui katub menuju bagian bawah yang disebut ventrikel. Katub ini bermanfaat untuk mencegah darah dalam jantung untuk berbalik arah.

Agar seorang anak dapat bertumbuh dan berkembang, jantung perlu mempertahankan fungsi normalnya untuk memberikan aliran darah ke seluruh tubuh secara optimal. Istilah "gagal jantung" dideskripsikan sebagai keadaan jantung yang tidak bekerja secara normal. Bukan berarti jantung berhenti bekerja, namun jantung tidak bekerja sebagaimana mestinya. ${ }^{1}$

Gagal jantung terjadi ketika jantung tidak adekuat untuk memenuhi kebutuhan metabolisme tubuh. Pada stadium awal dari gagal jantung, berbagai mekanisme kompensasi dilakukan untuk memenuhi fungsi metabolisme normal. Ketika mekanisme ini sudah tidak efektif, akan menyebabkan terjadinya manifestasi klinik yang berbahaya. ${ }^{2}$

Insiden dan prevalensi gagal jantung pada anak belum diketahui, sebagian besar karena belum adanya klasifikasi universal tetap yang digunakan. Beban terbesar pada kejadian gagal jantung pada anak berasal dari anak-anak yang dilahirkan dengan malformasi kongenital. Diperkirakan 15$25 \%$ anak dengan penyakit jantung struktural berkembang menjadi gagal jantung. Walaupun kasus kardiomiopati relatif jarang, namun sekitar $40 \%$ dari pasien yang mengalami gagal jantung kardiomiopati dengan gejala hebat harus sampai melakukan transplantasi bahkan dapat menyebabkan kematian. ${ }^{3}$

Gagal jantung pada anak-anak kurang mendapat perhatian karena kesulitan dalam pengumpulan data untuk evaluasi secara prospektif dan memperoleh izin. ${ }^{4}$ Belum ditemukan data di Indonesia, tetapi di Amerika tahun 2012, diketahui 18/100.000 anak atau 14.000 anak per tahun masuk rumah sakit karena gagal jantung. ${ }^{6}$ Pada penelitian di Belgia, terdapat $10 \%$ pasien anakdengan gagal jantung yang terdiri dari $6 \%$ dengan penyakit jantung bawaan (PJB) dan $80 \%$ dengan kardiomiopati.Jangkauan mortalitas anak dengan gagal jantung dari 4,7\% (PJB) sampai 25\% (kardiomiopati). Pada mayoritas pasien gagal jantung disertai PJB terdapat sekitar $15 \%$ disertai kardiomiopati atau miokarditis. ${ }^{6}$

Pada seorang anak yang masuk rumah sakit karena gagal jantung, biaya yang dibutuhkan akan lebih tinggi dibanding orang dewasa karena kebutuhan akan tindakan pembedahan atau intervensi lainnya. Tuntutan dari biaya pengobatan yang tinggi dapat mengganggu hubungan keluarga dan produktivitas ekonomi keluarga pasien. Ketika pasien meninggal karena gagal jantung, maka pengaruhnya bagi ekonomi keluarga sangat besar karena akan memengaruhi angka years of potencial life lost (YPLL). ${ }^{7}$

Years of potencial life lost adalah suatu angka yang digunakan untuk mengestimasi rata-rata waktu seseorang hidup dan tidak 
mati secara prematur. Pengukuran angka YPLL ialah untuk membantu mengukur kehilangan kualitas sosial dan ekonomi yang disebabkan oleh kematian prematur. Pengukuran ini bermanfaat untuk mencari penyebab spesifik dari tingkat kematian bagi kelompok usia muda. ${ }^{8}$

Penelitian ini bertujuan untuk mendapatkan gambaran karakteristik penderita gagal jantung pada bayi baru lahir di RSUP Dr. R. D. Kandou Manado tahun 2013-2015

\section{METODE PENELITIAN}

Jenis penelitian ialah deskriptif retrospektif yang dilakukan di Bagian Ilmu Kesehatan Anak RSUP Prof. Dr. R. D. Kandou Manado dari bulan Agustus sampai November 2016 dengan cara pengambilan data rekam medik.

Seluruh pasien di Bagian Ilmu Kesehatan Anak RSUP Prof. Dr. R. D. Kandou Manado periode tahun 2013-2015 menjadi populasi penelitian dan seluruh bayi baru lahir dengan gagal jantung merupakan sampel penelitian. Variabel penelitian terdiri dari: jenis kelamin, gambaran klinis (demam, sianosis, sesak napas), pemeriksaan antropometri (berat badan), tanda vital (nadi, respirasi, suhu), pemeriksaan fisik kepala (konjungtiva anemis, sklera ikterik), pemeriksaan fisik paru (retraksi, rhonki, wheezing), pemeriksaan fisik jantung (bising, gallop), pemeriksaan ekokardiografi, foto toraks, laboratorium (hematokrit, hemoglobin, leukosit, trombosit, bilirubin total dan direk, serta elektrolit (kalsium, natrium, kalium dan klorida).

Jenis data yang dikumpulkan meliputi: nama, nomor rekam medik, usia, jenis kelamin, gambaran klinis, pemeriksaan fisik, pemeriksaan penunjang pada bayi baru lahir dengan gagal jantung yang diambil dari rekam medik di Bagian Ilmu Kesehatan Anak RSUP Prof. Dr. R. D. Kandou Manado periode tahun 2013-2015.

\section{HASIL PENELITIAN}

Sampel penelitian diambil dari rekam medik yang berasal dari pusat rekam medik
RSUP Prof. Dr. R. D. Kandou Manado. Selama periode 1 Januari 2013-31 Desember 2015 terdapat 53 pasien dengan diagnosis gagal jantung. Peneliti berhasil mendata 25 catatan rekam medik dengan diagnosis gagal jantungpada bayi baru lahir sedangkan 28 rekam medik lain tidak ditemukan. Dari 25 sampel, terdapat 22 sampel yang memenuhi kriteria inklusi; 3 sampel menunjukkan usia yang lebih dari 28 hari.

Umumnya penderita dengan diagnosis gagal jantung ditegakkan sebagai diagnosis komplikasi dan bukan merupakan diagnosis utama. Pada sampel penelitian, gagal jantung muncul disertai dengan beberapa penyakit komorbid berupa sepsis, pneumonia, kolestasis, dan beberapa penyakit lainnya.

\section{Jenis kelamin}

Pada hasil penelitian ditemukan jumlah bayi laki-laki (55\%) yang menderita gagal jantung lebih banyak dari pada bayi perempuan $(45 \%)$.

\section{Gambaran klinis}

Terdapat beberapa gambaran klinis yang ditunjukan pada pasien gagal jantung pada bayi baru lahir yaitu: demam (68\%), sianosis (64\%), dan sesak napas (45\%).

\section{Antropometri}

Pemeriksaan antropometri dilakukan untuk memeriksa status perkembangan bayi yang baru lahir (Tabel 1). Pada pemeriksaan antropometri, didapatkan ratarata berat badan sampel 3495,45 gram dengan simpang baku 789,35 dan nilai yang paling sering muncul ialah 3400 gram. Dari seluruh sampel, ditemukan $77 \%$ dengan berat badan normal, $18 \%$ dengan makrosomia, dan 5\% dengan berat badan lahir rendah.

\section{Tanda vital}

Tanda vital merupakan aspek penting untuk memantau keadaan bayi baru lahir. Tanda vital normal yang biasa diperiksa ialah tekanan darah, nadi, respirasi, dan suhu tetapi pada neonati tekanan darah biasanya tidak diukur (Tabel 2). 
Gautama, Kaunang, Tatura: Gambaran karakteristik gagal...

Tabel 1. Antropometri pasien gagal jantung pada bayi baru lahir

\begin{tabular}{llll}
\hline Variabel penelitian & n & Persentase \\
\hline Berat Badan & Mean (SD) & $3495,45(789,35)$ & \\
& Modus & 3400 & \\
& LBW $(<2500)$ & 1 & $5 \%$ \\
VLBW $(<1500)$ & 0 & $0 \%$ \\
& ELBW $(<1000)$ & 0 & $0 \%$ \\
Maksosomia & 4 & $18 \%$ \\
$(>4000)$ & & $77 \%$ \\
Normal & 17 & $100 \%$ \\
\hline
\end{tabular}

Tabel 2. Tanda vital penderita gagal jantung pada bayi baru lahir

\begin{tabular}{lccccc}
\hline \multicolumn{1}{c}{ Variabel penelitian } & Mean & $\begin{array}{c}\text { Standard } \\
\text { deviasi }\end{array}$ & Median & Minimum & Maksimum \\
\hline Nadi (N: 95-160 x/menit) & 152,86 & 13,07 & 152 & 130 & 180 \\
Respirasi (N: 30-50 x/menit) & 70,59 & 17,64 & 68 & 48 & 100 \\
Suhu (N: 36,6-37 $\mathrm{C}$ ) & 36,86 & 0,88 & 36,7 & 35 & 38,8 \\
\hline
\end{tabular}

\section{Pemeriksaan fisik}

Pada pemeriksaan fisik penderita gagal jantung ditemukan $41 \%$ dengan sklera ikterik dan yang menonjol juga ialah ditemukannya retraksi pada hampir seluruh sampel penelitian (Tabel 3).

Tabel 3. Pemeriksaan fisik penderita gagal jantung pada bayi baru lahir

\begin{tabular}{lcc}
\hline Variabel penelitian & n & Persentase \\
\hline $\begin{array}{l}\text { Kepala } \\
\text { Konjungtiva } \\
\text { Anemis }\end{array}$ & 2 & $9 \%$ \\
$\quad \begin{array}{l}\text { Sklera Ikterik } \\
\text { Paru-paru } \\
\text { Retraksi }\end{array}$ & 9 & $41 \%$ \\
$\quad$ Rhonki & 21 & $95 \%$ \\
$\quad$ Wheezzing & 3 & $14 \%$ \\
Jantung & 0 & $0 \%$ \\
Bising Pansistolik & 18 & $82 \%$ \\
$\quad$ Ejeksi & 3 & $14 \%$ \\
$\quad$ Sistolik & & \\
$\quad$ Tidak ada & 1 & $5 \%$ \\
$\quad$ Bising & 6 & $27 \%$ \\
\hline
\end{tabular}

Pada pemeriksaan jantung ditemukan $96 \%$ memiliki gejala bisisng yang terdiri dari $82 \%$ bising pansistolik dan $14 \%$ bising ejeksi sistolik. Gallop ditemukan sebesar 27\% dari sampel (Tabel 3).

\section{Pemeriksaan penunjang}

Pemeriksaan penunjang yang sering dilakukan pada sampel terdiri dari ekokardiografi dan foto toraks. Pada pemeriksaan ekokardiografi ditemukan gambaran jantung terbanyak ialah VSD sebesar $68 \%$. Pemeriksaan foto toraks menunjukkan $91 \%$ dengan gambaran normal dan 9\% dengan gambaran bercak infiltrat di kedua lapang paru (Tabel 4).

Selain pemeriksaan ekokardiografi dan foto thoraks, pemeriksaan laboratorium menjadi salah satu variabel penelitian (Tabel 5). Pada hasil pemeriksaan laboratorium didapatkan dominan terjadi penurunan hematokrit (45\%), hemoglobin (55\%), dan trombosit (68\%); terjadi peningkatan leukosit (73\%), bilirubin total (77\%), bilirubin direk (73\%)' dan kadar normal pada kalsium (50\%), natrium (46\%), kalium (68\%), dan klorida (54\%). 
Tabel 4. Pemeriksaan ekokardiografi dan foto thorakspasien gagal jantung pada bayi baru lahir

\begin{tabular}{lcc}
\hline \multicolumn{1}{c}{ Variabel penelitian } & n & Persentase \\
\hline Ekokardiografi & & \\
VSD & 15 & $68 \%$ \\
ASD & 2 & $9 \%$ \\
ASD dan VSD & 2 & $9 \%$ \\
PJB Lainnya & 3 & $14 \%$ \\
\hline Foto toraks & & \\
$\quad$ Normal & 20 & $91 \%$ \\
Bercak Infiltrat di kedua lapang paru & 2 & $9 \%$ \\
\hline
\end{tabular}

Tabel 5. Pemeriksaan laboratorium pasein gagal jantung pada bayi baru lahir

\begin{tabular}{lcc}
\hline \multicolumn{1}{c}{ Variabel penelitian } & n & Persentase \\
\hline Hematokrit & & \\
Normal $(37-47 \%)$ & 7 & $32 \%$ \\
Rendah $(<37 \%)$ & 10 & $45 \%$ \\
Tinggi $(>47 \%)$ & 5 & $23 \%$ \\
Hemoglobin & & \\
$\quad$ Normal $(13,5-19,5 \mathrm{~g} / \mathrm{dL})$ & 10 & $45 \%$ \\
Rendah $(<13,5 \mathrm{~g} / \mathrm{dL})$ & 12 & $55 \%$ \\
Tinggi $(>19,5 \mathrm{~g} / \mathrm{dL})$ & 0 & $0 \%$ \\
Leukosit & & \\
$\quad$ Normal $(4000-10000$ & 3 & $13 \%$ \\
/ $\mu \mathrm{L})$ & \\
Rendah $(<4000 / \mu \mathrm{L})$ & 3 & $14 \%$ \\
Tinggi $(>10000 / \mu \mathrm{L})$ & 16 & $73 \%$ \\
Trombosit & & \\
Normal $(150-450$ & 7 & $32 \%$ \\
$\left.10^{3} / \mu \mathrm{L}\right)$ & \\
Rendah $\left(<15010^{3} / \mu \mathrm{L}\right)$ & 15 & $68 \%$ \\
Tinggi $\left(>45010^{3} / \mu \mathrm{L}\right)$ & 0 & $0 \%$ \\
Bilirubin Total & & \\
Normal $(0,10-1,20$ & 0 & $0 \%$ \\
mg/dL) & & $0 \%$ \\
Rendah $(<0,10 \mathrm{mg} / \mathrm{dL})$ & 0 & $77 \%$ \\
Tinggi $(>1,20 \mathrm{mg} / \mathrm{dL})$ & 17 & $23 \%$ \\
Tidak Diperiksa & 5 & \\
\hline
\end{tabular}

\section{BAHASAN}

Penderita gagal jantung yang dirawat di Bagian Neonati RSUP Prof. Dr. R. D. Kandou Manado selama tahun 2013-2015 sebanyak 53 pasien. Dari 53 pasien, 22 pasien memenuhi kriteria inklusi penelitian sedangkan 28 rekam medik lainnya tidak ditemukan oleh karena sudah terlalu lama atau telah hilang dan 3 rekam medik lainnya ditemukan usia yang lebih dari 28

\begin{tabular}{lcc}
\hline Variabel penelitian & n & Persentase \\
\hline Bilirubin Direct & & \\
Normal $(<0,30 \mathrm{mg} / \mathrm{dL})$ & 1 & $4 \%$ \\
Tinggi $(>0,30 \mathrm{mg} / \mathrm{dL})$ & 16 & $73 \%$ \\
Tidak Diperiksa & 5 & $23 \%$ \\
Kalsium & & \\
Normal $(8,1-10,4 \mathrm{mEq} / \mathrm{dL})$ & 11 & $50 \%$ \\
Rendah $(<8,1 \mathrm{mEq} / \mathrm{dL})$ & 2 & $9 \%$ \\
Tinggi $(>10,4 \mathrm{mEq} / \mathrm{dL})$ & 1 & $5 \%$ \\
Tidak Diperiksa & 8 & $36 \%$ \\
Natrium / Sodium & & \\
Normal $(135-153 \mathrm{mEq} / \mathrm{L})$ & 10 & $46 \%$ \\
Rendah $(<135 \mathrm{mEq} / \mathrm{L})$ & 8 & $36 \%$ \\
Tinggi $(>153 \mathrm{mEq} / \mathrm{L})$ & 2 & $9 \%$ \\
Tidak Diperiksa & 2 & $9 \%$ \\
Kalium / Pottasium & & \\
Normal $(3,5-5,3 \mathrm{mEq} / \mathrm{L})$ & 15 & $68 \%$ \\
Rendah $(<3,5 \mathrm{mEq} / \mathrm{L})$ & 1 & $5 \%$ \\
Tinggi $(>5,3 \mathrm{mEq} / \mathrm{L})$ & 4 & $18 \%$ \\
Tidak Diperiksa & 2 & $9 \%$ \\
Klorida / Chloride & & \\
Normal $(98-109 \mathrm{mEq} / \mathrm{L})$ & 12 & $54 \%$ \\
Rendah $(<98 \mathrm{mEq} / \mathrm{L})$ & 5 & $23 \%$ \\
Tinggi $(>109 \mathrm{mEq} / \mathrm{L})$ & 3 & $14 \%$ \\
Tidak Diperiksa & 2 & $9 \%$ \\
\hline
\end{tabular}

hari. Berdasarkan jenis kelamin, ditemukan bayi laki-laki lebih banyak yaitu $55 \%$ sedangkan bayi perempuan $45 \%$.

Gambaran klinis berupa demam, sianosis, dan sesak napas ditemukan bervariasi karena gagal jantung itu sendiri ataupun oleh karena penyakit komorbid lainnya. Kinsey dan White $^{9}$ dalam penelitiannya menyatakan bahwa gagal jantung secara langsung dapat menyebab- 
kan terjadinya demam oleh karena peningkatan metabolisme, walaupun kebanyakan demam pada pasien gagal jantung disebabkan oleh infeksi paru-paru. Gagal jantung yang menyebabkan demam dengan mekanisme peningkatan metabolisme (hipermetabolisme) ialah melalui peningkatan kerja miokardial dan respirasi serta ekskresi katekolamin yang berlebihan. ${ }^{10}$ Salah satu penyakit komorbid yang menyebabkan tumpang tindihnya gejala khas gagal jantung ialah sepsis neonatorum yang dapat menimbulkan gejala demam, distres pernapasan, sianosis, apneu, dan gejala yang tidak spesifik lainnya. ${ }^{11,12}$ Pneumonia pada bayi baru lahir juga dapat menimbulkan gejala yang mirip dengan gagal jantung seperti takikardia, retraksi, hipoksemia dan grunting. ${ }^{13}$ Gejala sianosis pada gagal jantung disebabkan oleh karena kurangnya perfusi pada jaringan tubuh karena kegagalan jantung memompa darah ke jaringan tersebut. ${ }^{14}$ Selain penyakit jantung bawaan yang dapat menyebabkan sianosis, beberapa keadaan yang dapat menimbulkan sianosis juga seperti asfiksia pernapasan, sindrom distress pernapasan, pneumo-toraks, efusi pleura, dan berbagai keadaan lain dapat menyebabkan tidak spesifiknya gejala tersebut. ${ }^{15}$ Gejala sesak napas pada gagal jantung dapat terjadi disebabkan oleh karena perubahan patologik pada denyut jantung dan saturasi oksigen sehingga terjadi kesulitan atau terhentinya napas. ${ }^{16}$ Perubahan patologik paru-paru yang dapat terjadi oleh komplikasi gagal jantung yaitu hipertensi arteri pulmonal/pulmonary artery hypertention (PAH). Hipertensi arteri pulmonal menyebabkan terjadinya sesak napas oleh karena 3 perubahan yang terjadi yaitu; (1) lapisan otot arteri pulmonal yang tebal sejak masa fetus; (2) rendahnya saturasi oksigen; dan (3) peningkatan substrat vasokonstriktor seperti prostaglandin, leukotrien, tromboksan, dan endotelin bersamaan dengan penurunan substrat vasodilator seperti prostasiklin dan nitrik oksida (NO). Ketiga perubahan ini akan menyebabkan terjadinya vasokonstriksi arteri pulmonal dan hipertensi arteri pulmonal. ${ }^{17}$ Oleh karena itu, pada pemeriksaan tanda vital pasien ditemukan respirasi dan nadi yang meningkat dengan suhu yang bervariatif dari hipotermi, normal sampai hipertermi.

Pada pemeriksaan antropometri, paling banyak dijumpai berat badan yang tergolong normal (77\%), tetapi dari seluruh sampel ditemukan terdapat $18 \%$ yang memiliki berat badan yang tergolong makrosomia. Makrosomia merupakan suatu keadaan bayi yang memiliki berat badan lebih dari 4000 gr dan biasanya disebabkan berbagai faktor seperti genetik, diabetes gestasional dan ibu yang sudah memiliki diabetes sebelumnya. ${ }^{18}$ Pada penelitian Narchil dan Kulaylat. ${ }^{19}$ risiko seorang bayi terkena gangguan kongenital meningkat antara $2,5 \%$ sampai $12 \%$ pada bayi dengan ibu yang menderita diabetes. Salah satu gangguan kongenital yang dapat terjadi ialah penyakit jantung bawaan. ${ }^{19}$

Ikterus pada sampel penelitian ditemukan sebanyak 41. Pada dasarnya, hiperbilirubinemia fisiologik dapat terjadi pada seorang bayi yang baru lahir sampai minggu pertama kehidupan dan setelah itu gejala ikterus sudah tidak ditemukan, tetapi jika ikterus tetap bertahan atau muncul setelah usia tersebut, maka dapat dicurigai adanya kelainan hati pada pasien. ${ }^{20}$ Ikterus pada sampel ditemukan bersamaan dengan penyakit komorbid yaitu kolestasis yang disebabkan oleh sepsis. Kolestasis adalah terjadinya obstruksi pada aliran empedu dan menyebabkan terhambatnya aliran empedu. Keadaan ini dapat menyebabkan kondisi ikterus atau kekuningan pada kulit bayi. ${ }^{21}$ Walaupun jarang, keadaan ikterus dapat pula disebabkan oleh gagal jantung yaitu melalui terjadinya kongesti pasif pada hati atau hepatitis iskemik akut. ${ }^{22,23}$ Temuan gejala ikterus juga didukung oleh pemeriksaan bilirubin sampel yang menunjukkan peningkatan kadar bilirun total dari $77 \%$ sampel dan bilirubin direk dari $73 \%$ sampel penelitian.

Gejala berupa retraksi dan rhonki yang ditemukan paling banyak disebabkan oleh penyakit komorbid dari gagal jantung yaitu pneumonia. Pneumonia dapat menunjukkan gejala suara rhonki karena alveoli yang 
terisi oleh cairan atau pus yang diproduksi tubuh untuk melawan infeksi pada paruparu. ${ }^{13,24}$ Bayi dengan gagal jantung dapat menunjukkan gejala retraksi trakea oleh karena takipneu yang terjadi bersamaan dengan peningkatan edema pulmonal atau takipneu pada saat pemberian makan. ${ }^{25}$ Gejala rhonki bukanlah gejala spesifik untuk gagal jantung, melainkan menandakan terjadinya gangguan patologik pada paru-paru. $^{26}$

Bising pansistolik (82\%) dan bising ejeksi sistolik (14\%) merupakan jenis bising yang ditemukan pada penelitian ini. Bising pansistolik ialah karakteristik dari ventricular septal defect (VSD), sedangkan bising ejeksi sistolik merupakan karakteristik dari atrial septal defect (ASD). ${ }^{27}$ Hal tersebut mendukung hasil pemeriksaan ekokardiografi $^{28}$ yang menunjukan $68 \%$ pasien dengan gambaran VSD dan lainnya berupa ASD (9\%), ASD dengan VSD (9\%) dan PJB lainnya (14\%). Temuan ini didukung oleh penelitian $\mathrm{CDC}$ yang menyatakan bahwa VSD merupakan penyakit jantung bawaan terbanyak yang terjadi di dunia. ${ }^{29-30}$ Pada pemeriksaan foto toraks didapatkan $91 \%$ menunjukkan gambaran normal dan 9\% menunjukkan gambaran bercak infiltrat pada kedua lapang paru. Gambaran ini bukan merupakan gambaran yang spesifik untuk satu penyakit, melainkan menunjukan beberapa interpretasi yaitu pneumonia, TBC, aspirasi, edema kardiogenik pulmonal, dan lainnya. ${ }^{31}$

Pada penelitian didapatkan bahwa banyak sampel mengalami penurunan pada hematokrit $(45 \%)$ dan hemoglobin $(55 \%)$. Terjadi penurunan hematokrit dan hemoglobin dapat disebabkan oleh keadaan anemia akibat gagal jantung. Jika keadaan gagal jantung sampai menyebabkan terjadinya hipoperfusi pada ginjal, maka dapat terjadi dua mekanisme yaitu; (1) Aktivasi dari renin-angiotensin-aldosteron system (RAAS) yang menyebabkan hemodilusi dan (2) Penurunan produksi sel darah merah yang dapat menimbulkan keadaan anemia. ${ }^{32}$ Ditemukan pula terjadi penurunan pada pemeriksaan trombosit
(68\%), namun belum ada penjelasan pasti mengenai hubungan antara gagal jantung dengan trombositopenia. Keadaan trombositopenia dapat disebabkan oleh salah satu penyakit komorbid pada sampel penelitian yaitu sepsis. Pada sepsis, terdapat beberapa mekanisme terjadinya trombositopenia seperti cedera endotel, kerusakan yang dimediasi oleh imun dan aggregasi trombosit yang disebabkan oleh produk bakteri yang melekat pada membran trombosit. Selain sepsis, penyakit lain yang dapat menyebabkan keadaan trombositopenia ialah sindrom distres pernapasan, hipertensi pulmonal persisten, transfusi tukar, hipoksia kronik oleh karena insufisiensi plasenta, dan keadaan lainnya. ${ }^{33}$

Peningkatan leukosit yang banyak dijumpai pada sampel penelitian (73\%) dapat disebabkan oleh karena keadaan infeksi atau inflamasi pada tubuh. ${ }^{34}$ Belum ada penelitian yang menunjukkan pengaruh secara langsung gagal jantung terhadap peningkatan leukosit. Pada sampel penelitian ini banyak ditemukan penyakit komorbid sepsis yang menyebabkan peningkatan leukosit.

Pada pemeriksaan elektrolit, ditemukan hampir semua elektrolit yang diperiksa dalam batas normal seperti pada kalsium ditemukan 50\% sampel memiliki kadar normal, natrium $46 \%$, kalium $68 \%$ dan klorida 54\%. Bila pada pemeriksaan ditemukan abnormalitas pada kadar elektrolit, maka hal ini dapat menunjukan komplikasi yang berbahaya dari gagal jantung yang diderita. Abnormalitas elektrolit dapat terjadi disebabkan oleh gagal jantung melalui aktivasi faktor neurohumoral yang menyebabkan stimulasi pada RAAS dan stimulasi simpatoadrenergik. Mekanisme lain terjadinya gangguan elektrolit karena gagal jantung ialah oleh karena penurunan cardiac output yang menyebabkan penurunan alirah darah ke ginjal dan gangguan keseimbangan ekskresi air dan elektrolit. ${ }^{35}$ Selain itu, salah satu gambaran yang dapat bermakna pada hasil penelitian ini ialah adanya nilai penurunan kadar natrium yaitu 36\% dari sampel. Keadaan hiponatremia dapat terjadi 
pada pasien gagal jantung oleh karena penurunan ekskresi air yang disebabkan oleh pelepasan angiotensin dan vasopresin. Keadaan hiponatremia harus segera dikoreksi karena natrium berperan penting sebagai faktor pertumbuhan yang menstimulasi proliferasi sel, sintesis protein, dan meningkatkan massa sel. Bila keadaan hiponatremia tidak dikoreksi dapat menyebabkan gagal pertumbuhan. ${ }^{36,37}$

Keterbatasan penelitian ini ialah pada proses pengambilan data terdapat beberapa rekam medik yang tidak ditemukan.

\section{SARAN}

Perlu dilakukan penelitian lanjutan dengan desain penelitian analitik untuk mencari faktor-faktor spesifik lainnya yang dapat menyebabkan terjadinya gagal jantung pada bayi baru lahir.

\section{SIMPULAN}

Berdasarkan hasil penelitian ini dapat disimpulkan bahwa jenis kelamin laki-laki yang dominan. Gambaran klinis berupa demam, sianosis dan sesak napas sering dijumpai. Berat badan cenderung normal walaupun terdapat beberapa bayi yang ditemukan dengan makrosomia. Gambaran tanda vital berupa takikardia dan takipneu sering dijumpai. Gambaran sklera ikterus lebih sering dijumpai daripada konjungtiva anemis. Tanda retraksi ditemukan pada hampir seluruh sampel penelitian, sedangkan rhonki dan wheezing jarang ditemukan. Bising yang paling sering didapatkan ialah bising pansistolik sedangkan gallop jarang dijumpai. Pada ekokardiografi, gambaran yang paling sering ialah ventricular septal defect (VSD) sedangkan pada foto toraks kebanyakan didapatkan gambaran normal. Pada pemeriksaan laboratorium, ditemukan kadar kalsium, natrium, kalium dan klorida yang normal, terjadi penurunan kadar hematokrit, hemoglobin, trombosit, dan peningkatan kadar leukosit, bilirubin total, dan bilirubin direk.

\section{DAFTAR PUSTAKA}

1. American Heart Association. Heart failure in children and adolescents. 25 Agustus
2016. [cited 8 September 2016]. Available from: http://www.heart.org/HEARTORG/Co nditions/HeartFailure/AboutHeartFailur e/Heart-Failure-in-Children-andAdolescents_UCM_311919_Article.jsp

2. Bernstein D. Heart failure. In: Kliegman RM, Stanton BF, Geme JW, Schor NF, Behrman RE, editors. Nelson Textbook of Pediatrics (20th ed). Philadelphia: Elsevier, 2016; p. 2282-8.

3. Madriago E, Silberbach M. Heart failure in infants and children. AAP publication, 2009. [cited 8 September 2016]. Available from: http://pedsinreview.aappublications.org /content/31/1/4.

4. Webster G, Zhang J, Rosenthal D. Comparison of the epicemiology and co-morbidities of heart failure in the pediatric and adult populations: a retrospective, cross-sectional study. BMC Cardiovasc Disord. 2006:6;23.

5. CDC. Heart Failure Fact Sheet. [cited 10 September 2016]. Available from: http://www.cdc.gov/dhdsp/data_statisti cs/fact_sheets/fs_heart_failure.htm.

6. Rossano JS, Jang GY. 2014. Pediatric heart failure: Current state and future possibilities. Korean Circ J 2015;45(1):1-8)

7. Hsu DT, Pearson GD. Heart failure in children Part I: History, etiology, and pathophysiology. Circ Heart Fail. 2009;2:63-70.

8. Gardner JW, Sanborn JS. Years of potential life lost (YPLL) - what does it measure?. PubMed, 1990. Available from:

http://www.ncbi.nlm.nih.gov/pubmed/2 083312

9. Kinsey D, White PD. Fever in congestive heart failure. Arch Intern Med (Chic). 1940;65(1):163-170.

10. Lees MH, Bristow JD, Griswold HE, Olmsted RW. Relative hypermetabolism in infant with congenital heart disease and undernutrition. [cited 22 November 2016]. Available from: https://www.ncbi.nlm.nih.gov/pubmed/ 14320026.

11. Bonadio WA, Hennes H, Smith D, Ruffing $R$, Melzer-Lange $M$, Lye $P$, Isaacman D. Reliability of observation 
variables in distinguishing infectious outcome of febrile young infants. Pediatr Infect Dis J. 1993;12:111-4.

12. Gerdes JS. Clinicopathologic approach to the diagnosis of neonatal sepsis. Clin Perinatol. 1991;18:361-81.

13. Bennett NJ. Pediatric pneumonia clinical presentation. Medscape. [cited 14 November 2016]. Available from: http://emedicine.medscape.com/article/ 967822-clinical.

14. Diller GP, Gatzoulis MA. Pulmonary vascular disease in adults with congenital heart disease. Circulation. 2007;115:1039-1050.

15. News Medical Life Science. Cause of cyanosis. 2012. [cited 14 November 2016]. Available from: http://www. news-medical.net/health/Causes-ofcyanosis.aspx.

16. Aggarwal R, Sighal A, Deorari AK, Paul VK. Apneua in newborn. Department of Pediatrics All India Institute of Medical Sciences Ansari Nagar. [cited 15 November 2016]. Available from: http: $\quad / /$ www.newbornwhocc. org/pdf/Apnea.pdf.

17. Mendoça CT, Coelho TH. Pathophysiology of pulmonary hypertension in newborns: therapeutic indications. Rev Port Cardiol. 2013; 32(12):1005-1012.

18. Jazayeri A. Macrosomia. Medscape. [cited 14 November 2016]. Available from: http://emedicine.medscape.com/article/ 262679-overview.

19. Narchi H, Kulaylat N. Heart disease in infants of diabetic mothers. PubMed. [cited 14 November 2016]. Available from: https: //www.ncbi.nlm.nih.gov/ pmc/articles/PMC3232483/.

20. Porter ML, Dennis BL. Hyperbilirubinemia in the term newborn. Am Fam Physician. 2002; 65(4):599-607. [cited 15 November 2016]. Available from: http:

//www.aafp.org/afp/2002/0215/p599.ht $\mathrm{ml}$.

21. Herrine SK. Cholestasis. Merck Manuals. [cited 14 November 2016]. Available from: http: //www.merckmanuals. com/home/liver-and-gallbladderdisorders/manifestations-of-liverdisease/cholestasis.

22. Van Lingen $R$, Warshow U, Dalton HR,
Hussaini SH. Jaundice as a presentation of heart failure. J R Soc Med. 2005;98(8):357-9.

23. Agata ID, Balistreri WF. Evaluation of liver disease in the pediatric patients. [cited 15 November 2016]. Available from: http://www.columbia.edu/itc/hs/nursing /m6638/2003_2/session03/liver_disease .pdf.

24. Carter L. Rhonchi lung sound: Definition, causes \& treatment. Study.com. [cited 14 November 2016]. Available from: http://study.com/academy/lesson/rhonc hi-lung-sounds-definition-causestreatment.html.

25. Altman CA. Identifying newborns with critical congenital heart disease. [cited 15 November 2016]. Available from: http://www.uptodate.com/ contents/identifying-newborns-withcritical-congenital-heart-disease.

26. Kavanagh S. Cor pulmonale. 2008. [cited 15 Nov 2016]. Available from: http://patient.info/doctor/corpulmonale.

27. Frank JE, Jacobe KM. Evaluation and management of heart murmurs in children. America Family Phycisians. [cited 14 Nov 2016]. Available from: http://www.aafp.org/afp/2011/1001/p79 3.html.

28. America Heart Assossiation. What is Echocardiography? [cited 14 Nov 2016]. Available from: https://www. heart.org/idc/groups/heartpublic/@wcm /@ hcm/documents/downloadable/ucm _ 300438.pdf. Diakses tanggal $1 \overline{4}$ November 2016.

29. Botto LD, Correa A, Erickson D. Racial and temporal variations in the prevalence of heart defects. Pediatrics. 2001;107(3):e32.

30. Bjornard K, Riehle-Colarusso T, Gilboa SM, Correa A. Patterns in the prevalence of congenital heart defects, metropolitan Atlanta, 1978 to 2005. Birth Defects Res Part A Clin Mol Teratol. 2013;97(2):87-94.

31. Blanco S, Torres A. Differential diagnosis of pulmonary infiltrates in ICU patients. [cited 14 Nov 2016]. Available from: http://www.antimicrobe.org/ h04c.files/history/ e47_link.asp.

32. Tang YD, Katz SD. Anemia in chronic heart failure: Prevalence, etiology, clinical 
correlates, and treatment options. [cited 15 Nov 2016]. Available from: http://circ.ahajournals.

org/content/circulationaha/113/20/2454 /F1.large.

33. Wong W, Glader B. Approach to the newborn who has thrombocytopenia. [cited 15 Nov 2016]. Availabl from: http://www.ohsu.edu/xd/health/services /doernbecher/research-education/ education/residency/upload/res_lounge throbocytopenia.pdf.

34. Abramson N, Melton B. Leukocytosis:
Basics of clinical assessment. Am Fam Physician. 2000;62(9):2053-60.

35. Cas LD, Metra M, Leierm CV. Electrolyte disturbances in chronic heart failure: Metabolic and clinical aspects. Clin. Cardiol. 1995;18:370-6.

36. Schwinger RH, Erdmann E. Heart failure and electrolyte disturbances. Methods Find Exp Clin Pharmacol. 1992; 14(4):315-25.

37. Haycock GB. The influence of sodium on growth in infancy. Pediatr Nephrol. 1993;7(6):871-5. 